\title{
PERANAN ELPIDIUS VAN DUIJHOVEN TERHADAP PENYEBARAN AGAMA KATOLIK DI SIMALUNGUN
}

\author{
Niko Adriano Hutabarat ${ }^{1}$ \\ Lister Eva Simangunsong ${ }^{2}$ \\ Fakultas Ilmu Sosial Universitas Negeri Medan \\ nikoadriano@gmail.com
}

\begin{abstract}
ABSTRAK
Penelitian ini bertujuan untuk mengetahui tentang proses penyebaran Agama Katolik oleh Elpidius van Duijhoven, untuk mengetahui bagaimana kondisi religi masyarakat Simalungun khususnya Saribudolok sebelum dan sesudah kedatangan Elpidius van Duijhoven, untuk mengetahui apa saja peranan yang dilakukan Pastor Elpidius dalam menyebarkan Agama Katolik di Simalungun. Penelitian ini merupakan penelitian Historis dengan data kualitatif. Dengan mengumpulkan datadata, penulis melakukan penelitian kepustakaan dengan mengumpulkan bukubuku, dokumen, dan sejenisnya. Selain itu untuk mendukung data, penulis juga melakukan penelitian lapangan dengan observasi,wawancara dan data dokumentasi. Dari hasil penelitian yang dilakukan maka diketahui bahwa sebelum Pastor Elpidius datang ke Simalungun, masyarakat Simalungun khususnya Saribudolok saat itu sudah memiliki aliran kepercayaan sendiri,Setelah kedatangan Pastor Elpidius sejak tahun 1934, masyarakat Saribudolok berangsur-angsur mau menerima Agama Katolik. Agama Katolik pertama kali disebarkan Di Sabah Dua kemudian Sirpang Sigodang, Pematang Raya, Pematang Purba kemudian ke Haranggaol, Saribudolok hingga ke Karo dan Aceh Tenggara. Berbagai peranan yang dilakukan PastorElpidius antara lain Mendirikan Gereja di Purba Hinalang dan Saribudolok serta sekolah.
\end{abstract}

Kata Kunci : Elpidius Van Duijhoven, Katolik, Simalungun 


\section{PENDAHULUAN}

Indonesia merupakan negara yang mempunyai keanekaragaman budaya yang luar biasa. Selain budaya, Indonesia juga merupakan negara yang mempunyai berbagai macam agama baik agama yang sah menurut negara maupun agama lokal yang sudah ada sejak lama.Salah satu Agama yang terdapat di Indonesia adalah agama Katolik, Agama yang berpusat di Roma ini mempunyai pengikut sekitar 3 $\%$ di Indonesia. Agama Katolik hampir tersebar di seluruh daerah di Indonesia terutama di Sumatera Utara. Salah satu kabupaten di Sumatera Utara yang mempunyai cukup banyak masyarakat yang beragama Katolik adalah Kabupaten Simalungun. Kabupaten Simalungun beribukota di Pematang Raya. Kabupaten Simalungun memiliki 31 kecamatan dan di dominasi oleh suku Batak Simalungun. Kabupaten Simalungun berbatasan dengan beberapa kabupaten lainnya, seperti di Utara berbatasan dengan Kabupaten Deli Serdang dan Serdang Bedagai, di Selatan dengan Kabupaten Toba Samosir, Barat dengan Kabupaten Karo dan Timur dengan Kabupaten Asahan.

Salah satu misionaris yang menyebarkan agama Katolik di Simalungun adalah Elpidius Van Duijhoven yang dikenal oleh masyarakat Simalungun sebagai Oppung Dolok. Menarik jika kita melihat peranan dari misionaris ini. Misionaris yang berasal dari Belanda ini sangat melekat di hati masyarakat Simalungun bahkan sampai ke kawasan Aceh Tenggara. Peranan Misionaris ini dapat dilihat dari banyaknya masyarakat Simalungun yang menjadi umat Katolik, seperti dapat dilihat di buku karangan Simon Saragih (2014:23) "Sehubungan dengan itu Elpidius disibukkan dengan masuknya umat ke Katolik dalam jumlah relatif besar untuk ukuran kecamatan di beberapa desa".

Simalungun merupakan daerah yang menjadi sasaran para misionaris yang datang dari Eropa seperti Jerman, Inggris, Amerika dan Belanda. Hal ini hampir sama dengan wilayah Tapanuli yang didominasi oleh misionaris yang berasal dari Rheinische Missionsgesellscahft atau RMG seperti L.I Nomemsen. Menarik untuk mengetahui alasan Elpidius van Duijhoven menjadi Misionaris di Indonesia. Sebelum Elpidius datang ke Simalungun, sebelumnya telah dikirim seorang 
misionaris bernama Pastor Aurelius Kerkers tetapi cukup kesulitan untuk meyebarkan agama Katolik di Simalungun.

Elpidius Van Duijhoven merupakan seorang pastor Katolik yang berasal dari Belanda dan menyebarkan agama Katolik di Simalungun hampir 59 tahun. Elpidius van Duijhoven lahir dari pasangan Belanda bernama Henricus Van Duijhoven dan Joanna Pennings pada 7 Oktober 1906 di Erp salah satu wilayah di Belanda. Elpidus menjadi imam katolik pada 11 Maret 1933 di Usia 27 tahun dan datang ke Indonesia tepat pada tanggal 17 januari 1934 dengan tujuan Batavia dan pada tanggal 16 Februari 1934 tiba di Belawan dan ditempatkan di Pematang Siantar.Menarik untuk lebih mengenal tokoh ini, bagaimana Elpidius Van Duijhoven bisa berbaur dengan masyarakat Simalungun untuk menyebarkan agama Katolik yang tentunya ajaran yang baru untuk masyarakat Simalungun. Elpidius Van Duijhoven dapat masuk ke dalam kehidupan masyarakat Batak khususnya Batak Simalungun, bahkan sampai saat ini masyarakat Katolik di Simalungun atas masih sulit untuk melupakan jasa Pastor ini, padahal Elpidius Van Duijhoven sudah hampir 25 tahun wafat.

Berdasarkan latar belakang, identifikasi masalah dan batasan masalah di atas, maka rumusan masalah dalam penelitian ini adalah : Bagaimana Kondisi Religi masyarakat Simalungun/ Saribudolok sebelum kedatangan Elpidius Van Duijhoven? , Bagaimana penyebaran Agama Katolik oleh Elpidius di Simalungun? Serta, Bagaimana Peranan Elpidius Van Duijhoven dalam menyebarkan Agama Katolik di Simalungun tahun 1934-1990?

\section{METODE DAN FOKUS PENELITIAN}

Adapun metode yang digunakan dalam penelitian ini adalah metode penelitian sejarah. Teknik pengumpulan data yang digunakan antara lain: Field Research (penelitian lapangan), selanjutnya mengkaji literatur dan sumber lain guna memperoleh data. Metode Studi Lapangan ini dilakukan dengan mencari dan mengumpulkan data dan juga mengolah data sebanyak-banyaknya dari data yang ada di lapangan. Metode ini dilakukan dengan menggunakan pendekatan deskriptif kualitatif dengan strategi penelitian yang mengungkapkan fakta yang jelas tentang gejala-gejala yang ada pada suatu objek penelitian. Studi pustaka (Library 
Research) digunakan untuk untuk melengkapi teknik pengumpulan data, maka sebagai pelengkap untuk memperoleh pengetahuan teoritis dari pendapat para ahli dari berbagai buku dan juga arsip-arsip atau dokumen, artikel-artikel di dalam majalah atau surat kabar yang berkaitan dengan topik penelitian serta literatur lain yang mendukung.

\section{HASIL DAN PEMBAHASAN}

Simalungun merupakan salah satu kabupaten yang berada di Sumatera Utara. Simalungun letaknya diapi toleh 8 kabupaten yaitu Kabupaten Serdang Bedagai, Deli Serdang,Karo, Tobasa, Samosir, Asahan, Batubara, dan Kota Pematang siantar.Letak astronomisnya antara $02^{\circ} 36^{\prime}-03^{\circ} 18^{\prime}$ Lintang Utara dan $98^{\circ} 32^{\prime}-99^{\circ} 35^{\prime}$ Bujur Timur dengan luas $4.386,60 \mathrm{~km}^{2}$ berada pada ketinggian $0-1.400$ meter di atas permukaan laut dimana 75 persen lahannya berada pada kemiringan 0-15\%.

\section{Kecamatan Silimakuta}

Kecamatan Silimakuta merupakan salah satu kecamatan yang ada di Kabupaten Simalungun. Luas Wilayah dari Kecamatan Silimakuta adalah 74,16 $\mathrm{Km}^{2}$. Ketinggian Wilayah ini berkisar antara $751-1.400 \mathrm{~m}$ di atas permukaan laut. Letak Kecamatan ini diapit oleh 4 kecamatan lainnya.Kecamatan Silimakuta mencakup 1 kelurahan dan 6 Desa atau Nagori yaitu Keluharan Saribudolok. Penduduk Kecamatan Silmakuta di tahun 2014 mencapai 15.114 jiwa yang terdiri dari 7.658 laki-laki dan 7.456 perempuan. Sedangkan di lokasi penelitian sendiri yaitu kelurahan Saribudolok jumlah penduduk sebesar 8.221 jiwa atau sekitar 54,4 persen dari total poenduduk kecamatan Silimakuta.

\section{Kelurahan Saribudolok}

Saribudolok sendiri merupakan satu-satunya kelurahan yang ada di Kecamatan Silimakuta. Menurut data yang di dapat peneliti dari kantor kelurahan, jumlah penduduk di Kelurahan Saribudolok berjumlah 8.221. Penduduk Saribudolok terdiri dari berbagai macam etnis, antara lain, etnis Batak Karo, Batak Simalungun, Batak Toba, Jawa dan Cina. Agama yang dianut oleh penduduk Saribudolok di dominasi oleh Agama Kristen yang mencapai $85 \%$, kemudian 
Agama Islam $13 \%$ dan Budha $2 \%$.Kelurahan Saribudolok memeliki 10 lingkungan dan 29 Rukun Tetangga (RT), dan rata-rata kepadatan penduduk di Saribudolok 278 orang per Kilo Meter. Mata pencaharian masyarakat Saribudolok yang utama adalah Petani. Ini dikarenakan Saribudolok memiliki lahan pertanian yang subur.

\section{Kondisi Religi Masyarakat Saribudolok Sebelum Kedatangan Elpidius van} Duijhoven

Setiap masyarakat tentunya memiliki kebudayan tersendiri untuk melangsungkan kehidupannya salah satunya tentu di bidang agama atau religi. Masyarakat Simalungun khususnya Saribudolok sudah mempunyai aliran kepercayaan sendiri sebelum kedatangan Elpidius van Duijhoven di tahun 1934. Sebelum kedatangan Elpidius masyarakat Simalungun sudah mempunyai aliran kepercayaan tradisional. Selain aliran kepercayaan masyarakat Simalungun sudah ada yang memeluk Agama Islam maupun Kristen Protestan.

Agustono (2012:239) dalam bukunya Sejarah Etnis Simalungun Mengatakan:

Selain Naibata yangkitasebut diatas, orang Simalungun juga percaya akan makhluk-makhluk gaib yang merupakan sembahan satu-satu keluarga atau marga disebut: sinumbah dan simagod. Sinumbah dalam pemahaman orang Simalungun adalah roh-roh gaib yang mendiami tempat-tempat keramat yang ada kaitannya dengan kaitannya sejarah leluhur suatu keluarga atau marga yang lokasinya dinamakan "Parsinumbahan".

Agustono (2012:240) juga mengatakan:

Selain Sinumbah yang identik dengan parsinumbahan, orang Simalungun percaya juga bahwa kuasa dari nenek moyang mereka bisa hadir dalam bentuk Simagod, yang sewaktu dapat hadir bila dipanggil melalui ritual yang disebut "pahutahon" atau "pasiarhon" dengan membunyikan seperangkat alat musik tradisional Simalungun(gonrangsimalungun).

Berdasarkan keterangan diatas dapat kita lihat bahwa masyarakat Simalungun sudah mempunyai aliran kepercayaan yaitu "Sinumbah" dan "Simagod". Aliran kepercayaan ini sudah ada sejak turun temurun dan merupakan aliran kepercayaan asli Masyarakat Simalungun. Selain itu dalam wawancara dengan bapak Alfian Purba pada tanggal 08 Juni 2016 menerangkan bahwa di daerah Saribudolok sudah ada HKBPS yang dikemudian hari menjadi GKPS. 
Bapak Alfian juga menerangkan bahwa hanya sebagian kecil masyarakat yang memeluk Agama Kristen. Sebagian masyarakat Saribudolok masih Atheis atau mempercayai nenek moyang mereka.

Dalam wawancara dengan Bapak Simon Saragih pada tanggal 10 Juni 2016, Bapak Simon Saragihmengatakan masyarakat Saribudolok sudah mengenal Agama Kriten. Ini dikarenakan sudah ada masyarakat yang masuk gereja GKPS dan Pusat GKPS cukup dekat dengan Saribudolok yaitu Pematang Raya. Bapak Simon Saragih juga mengatakan masyarakat Saribudolok juga memeluk agama tradisional seperti Parmalim di Silindung.Dari keterangan ini dapat kita ketahui bahwa masyarakat Saribudolok sudah memeluk Agama Kristen dengan adanya Gereja HKBPS atau GKPS tapi itu hanya sebagian kecil dan ada juga masyarakat yang masih Atheis. Masyarakat Simalungun khususnya Saribudolok sudah mempunyai agama tradisional sejenis Parmalim di daerah Silindung maupun Danau Toba. Agama tradisional tersebut adalah Sinumbah dan Simagod.

\section{Masuk dan Penyebaran Agama Katolik Di Simalungun}

Di Simalungun sendiri Agama Katolik baru datang pada bulan Juli di tahun 1931 yang di bawa oleh pastor Aurelius Kenkers. Pastor Kenkers awalnya ditempatkan di Tanjung Balai dan kemudian dipindahkan di Medan lalu ke Pematang Siantar. Menurut Joosten (2008:126) "Boleh dikatakan, Pastor Aurelius inilah pendiri gereja Katolik Pematang Siantar. Dia mempermandikan orang-orang yang pertama masuk menjadi Katolik dan dia mengangkat katekis yang pertama yaitu: Kenan Hutabarat.Stasi atau Gereja pertama yang didirikan di Siantar adalah Gereja di Laras daerah perkebunan dekat kota Pematang Siantar pada tahun 1931.

Menurut penuturan Bapak Simon Saragih dalam wawancara pada tanggal 10 Juni 2016 pastor Aurelius hanya berkarya di Siantar saja dikarenakan kurangnya tenaga Misionaris pada saat itu dan Aurelius beranggapan di Simalungun Atas sepi penduduk dan dia lebih berkonsentrsi di PematangSiantar. Bapak SimonSaragih juga mengatakan Pastor Aurelius akhirnya meminta satu misonaris lagi untuk menyebarkan ajaran Katolik di Simalungun atas dan permintaan itu akhirnya dikabulkan dengan mengirimkan Pastor Elpidius van Duijhoven. Pastor Elpidius 
sendiri sangat berminat menjadi Misionaris dan ke pedalaman dan Simalungun Atas menjadi tempat yang cocok untuk Pastor Elpidus van Duijhiven menjadi tempat berkarya.

Pastor Elpidius van Duijnhoven lahir dari pasangan Henricus van Duijnhoven dan Joanna Pennings pada tanggal 07 Oktober 1906 di desa Erp, Belanda. Nama yang diberi kepadanya sewaktu lahir adalah Franciscus. Dia adalah anak laki-laki pertama dan anak ketiga dari delapan bersaudara. Ia lahir di sebuah ladang pertanian kecil yang mereka yang disewa oleh orang tuanya di desa Erp. Orang tuanya harus bekerja keras untuk mendapatkan rejeki guna menghidupi delapan anak. Dari kedelapan bersaudara dua diantaranya cepat meninggal, dua orang berkeluarga, dua orang menjadi biarawati yakni Suster Cayetana dan Suster Elpidia dan dua orang lagi menjadi Imam yakni Pastor Marinus dan Pastor Elpidius sendiri. Pastor Elpidius juga mempunyai seorang paman dari pihak bapaknya yang menjadi Pastoryaitu Bruder Willebrordus. Bagi Elpidius menjadi Pastor tidak asing lagi. Karena semenjak masa kecilnya dia sudah mengenal Pastor. Dia tertarik menjadi Pastor karena melihat cara hidup Pastor di Biara, dekat kampung kelahirannya. Dia masuk biara pada tanggal 7 September 1925, mengikuti studi Filsafat dan Teologi seperti biasa dan pada tanggal 11 Maret 1933 dia ditahbiskan menjadi Imam Kapusin.

Menurut Joosten (2008:159) :

Pada tanggal 16 Februari 1934 Elpidius tiba di Belawan dan selanjutnya di tempatkan di Pematang Siantar. Di Nederland di sudah belajar sedikit Bahasa Indonesia. Di Pematang Siantar dia mendapat pelajaran bahasa Batak Toba dari Pastor Aurelius dan Katekis Kenan Hutabarat. Satu tahun kemudian secara resmi Misi Katolik diizinkan masuk ke Tanah Batak. Pastor Elpidius mendapat tugas berorientasi di daerah Simalungun, di sebelah Utara dan Timur Danau Toba. Di situ dia bekerja sampai dengan perpisahannya tahun 1985 .

Simon saragih dalam wawancara pada tanggal 10 Juni 2016 Mengatakan, proses masuknya Agama Katolik di Saribudolok dimulai dari Pematang Siantar kemudian bergeser ke Sabah Dua sekitar 7 km dari Pematang Siantar. Di Sabah Dua Elpidius mendirikan stasi dan terus berjalan hingga ke Sirpang Sigodang 
kemudian ke Pematang Raya. Di Pematang Raya proses persebaran banyak mengalami kendala di karenakan di Pematang Raya merupakan pusat dari GKPS. Pastor Elpidius van Duihoven kurang berhasil menyebarkan Agama Katolik di Pematang Raya. Setelah mengalami banyak rintangan di Pematang Raya, Elpidius menyebarkan Agama Katolik ke Pematang Purba kemudian ke Haranggaol dan terus ke Saribudolok hingga ke Karo dan Lau Deski Aceh Tenggara.

Hal yang hampir sama juga di sampaikan oleh Bapak Alfian Purba. Menurut Bapak Alfian Purba dalam wawancara pada tanggal 08 Juni 2016 awalnya persebaran Katolik di Simalungun khususnya Saribudolok berasal dari Siantar kemudian bergeser ke Sawah Dua dan kemudian mengunjungi Haranggaol lewat Pematang Purba dengan cara melewati jalan pintas berupa hutan belantara dan disana dia berhasil membaptis beberapa penduduk. Setelah jalan umum diperbaiki Pastor Elpidius tidak lagi melewati Pematang Purba tetapi melewati Simpang Haranggaol dan menyebarkan Agama Katolik di Simpang Haranggaol yang meliputi Purba Hinalang, Sipinggan dan Gajah Pokki. Setelah di Simpang Haranggaol Pastor Elpidius menuju Saribudolok dan sekitarnya. Kemudian Saribudolok dijadikan Pusat dari Penyebaran Agama Katolik di Simalungun Atas. Melihat perkembangan itu maka dipikirkan untuk membuka pusat pelayanan di daerah Saribudolok. Saribudolok sengaja dipilih karena desa itu merupakan pusat perdagangan dan letaknya sentral antara Pematangsiantar dan Aceh Tenggara, kebetulan juga di Saribudolok sudah ada stasi kecil. Stasi inilah yang menjadi pusat kegiatan gerejani bagi Elpidius pada awalnya.

Di tahun 1935 di tanggal 24 November pastor Elpidius berhasil membaptis orang pertama di Haranggaol yakni Maknir Paulus Sihaloho. Kemudian pada tanggal 23 Januari 1938 Pastor Elpidius telah membaptis kedua kali di Bandar Saribu Haranggaol, yakni Abel Sinaga, Darian Purba, Helena Br. Saragih dan Lucia Br. Simarmata.Setelah di Haranggaol, Pastor Elpidius pada tanggal 30 Januari 1938 membaptis Petrus Fidelis Datubara yang merupakan orang tua dari Mgr. AGP Pius Datubara. Setelah Purba Hinalang Pastor Elpidius berhasil membaptis di Saribudolok. Di Saribudolok Pastor Elpidius dibantu oleh rekannya Pastor Nepomucenus Hamers dan mengadakan pembaptisan pertama di Saribudolokpada 
tanggal 12 Maret 1939. Mereka yang dibaptis pada waktu itu adalah Cornelius Damanik dan Laurentius Sipayung.

Dalam penyebaran Agama Katolik di Simalungun, Pastor Elpidius van Duijhoven tidaklah sendiri. Sejak awal menyebarkan agama Katolik dari Sabah Dua hingga ke Tanah Karo dan Aceh Tenggara. Beberapa orang atau Katekis yang membantu Pastor Elpidius adalah Kenan Mase Hutabarat, kemudian Laur Viator Hutabarat yang menemani di Sabah Dua. Kemudian ada Petrus Datubara dari Purba Hinalang. Selain itu juga dibantu oleh Pastor Nepomucenus Hamers seorang Pastor yang bertugas di Sidikalang. Sementara di Saribudolok sendiri Pastor Elpidius di temani oleh Katekis Bonaventura Yaep Lin Hin Purba.

Hal lain yang menarik kita cermati mengenai Pastor Elpidius adalah cara beliau menyebarkan Agama Katolik. Menurut penjelasan dari Bapak F.X Purba yang peneliti wawancarai pada tanggal 10 Juni 2016 sosok Elpidius merupakan sosok yang sederhana dan mau memberikan pikiran serta tenaga untuk membangun gereja. Menurut penuturan Bapak F.X Purba, Elpidius merupakan orang yang benar-benar meneladani sosok Fransiskus Asisi. Pastor Elpidius dalam meyebarkan agama Katolik tidak segan untuk membantu semua orang dari berbagai kalangan baik Katolik maupun Non-Katolik. Pastor Elpidius bukan merupakan seorang yang pandai berdiplomasi. Dengan sikapnya yang demikian sehingga banyak masyarakat Simalungun yang tertarik.

Selain itu menurut bapak Alfian Purba Masyarakat Simalungun khususnya Saribudolok mau menerima ajaran Pastor Elpidius van Duijhoven dikarenakan berbagai alasan, menurut Bapak Alfian ada tiga hal, Hal yang pertama yaitu menyangkut profil. Menurut penjelasan Bapak AlfianPurbaPastor Elpidius van Duijhovenmerupakan sosok yang tenang, selain itu Pastor Elpidius merupakan seseorang yang penuh perhatian, bukan hanya kepada mereka yang Kristen, salah satu bentuk perhatian Pastor Elpidius dia selalu memberikan bantuan. Yang terakhir Pastor Elpidius selalu membawa obat kemanapun dia pergi dan memberikannya kepada warga yang membutuhkan. Obat yang dibawa uniknya hanya satu jenis yaitu Norid, obat diare. Tetapi obat tersebut digunakan untuk menyembuhkan semua penyakit. Dengan perkembangan umat yang demikian pesat 
dan juga luasnya daerah yang dilayani, Pastor Elpidius van Duijhoven pun tidak sanggup lagi sendirian. Selain dibantu oleh Katekis ia akhirnya dibantu oleh misionaris lain di antaranya: P. Henricus Blaijs, OFM Cap (Nopember 1963 - April 1968) dan P. Evaristus Albers, OFM Cap (Februari 1966 - Agustus 1974). Dengan didukung oleh para Katekis jumlah umat pun bertumbuh begitu pesat. Katekis selalu bersedia menemani mereka mengunjungi, mendampingi dan memimpin umat dengan katekese dan ibadat.

Menurut Purba (1998:26) "Umat Katolik di Setasi Induk P. Siantar I-II, Perdagangan dan Seribudolok sebanyak 38.638 jiwa (Tinjauan Tahunan, Stistik, Keuskupan Agung Medan, Keadaan 31.12.1992:6)". Jika kita melihat data tersebut sudah banyak umat Katolik yang tersebar di Pematang Siantar, Perdagangan dan Saribudolok. Seiring perjalanan waktu menurut data yang dikeluarkan Paroki Saribudolok umat Paroki Saribudolok sudah mengalami peningkatan yang signifikan. Data yang di dapat penulis dari Paroki Saribudolok per 31 Desember 2009 Paroki Saribudolok sudah berjumlah 61 Stasi atau gereja dan 5 Persiapan stasi. Jadi Paroki Saribudolok sudah memiliki 66 stasi dengan jumlah umat sekitar 30.553 dan itu hanya di wilayah Paroki Saribudolok sendiri. Tentu jumlah ini merupakan andil besar dari Pastor Elpidius Van Duijhoven yang menyebarkan Agama Katolik di Simalungun khususnya Saribudolok.

Dalam meyebarkan agama katolik tentunya banyak kendala yang dilalui oleh Pastor Elpidius Van Duijhoven. Dalam wawancara dengan Bapak Alfian Purba banyak sekali tantangan atau hambatan yang dihadapi oleh Pastor Elpidius. Bapak Alfian mengatakan Elpidius sering dicobai atau diganggu oleh masyarakat sekitar yang tidak ingin menerima ajaran Agama Katolik.Selain itu Bapak Alfian Purba juga menjelaskan tantangan lain ialah kondisi geografis berupa alam yang saat itu sulit untuk dijangkau. Selain itu kondisi jalan pada saat itu sangat memprihatinkan dan sistem informasi serta kendaraan yang saat itu belum ada. Bapak Alfian Purba juga mengatakan Pastor Elpidius diterima oleh hampir semua penguasa setempat atau raja-raja setempat, ini mungkin dikarenakan profil Pastor Elpidius yang lembut dan sederhana. Bapak Simon Saragih juga mengatakan hal yang hampir sama dia mengatakan kendala yang dihadapi oleh Pastor Elpidius van Duijhoven adalah 
gangguan-gangguan dari para dukun yang tidak suka dengan Pastor Elpidius van Duijhoven.Pada suatu Minggu di tahun 1940 saat Elpidius hendak memimpin misa seorang dukun besar dari Bandar Saribu Harang Gaol, Oppung Parbongbongan, mendatanginya bermaksud untuk menguji Pastor Elpidius van Duijhoven.

\section{Kondisi Religi Masyarakat Simalungun Setelah Kedatangan Elpidius van Duijhoven}

Kondisi tentu berubah setelah kedatangan Elpidius van Duijhoven. Banyak Masyatakat Simalungun Atas khususnya masyarakat Saribudolok yang memeluk Agama Katolik. Meskipun Pastor Elpidius berhasil mendirikan banyak gereja atau Stasi di Simalungun tetap saja waktu itu masih sebagian masyarakat yang memeluk Agama Katolik.

Menurut Bapak Alfian Purba yang peneliti wawancarai tanggal 7 juni 2016, tentu kondisi masyarakat Saribudolok berubah total. Di Purba Hinalang sendiri sekitar $85 \%$ masyarakat adalah penganut Agama Katolik. Pada waktu itu di Purba Hinalang sendiri sudah ada HKBPS yang kemudian berubah menjadi GKPS tetapi masyarakat Purba Hinalang lebih banyak yang memeluk Agama Katolik.

Sedangkan bapak F.X Purba mengatakan kedatangan Pastor Elpidius van Duijhoven ke Simalungun tentu berangsur-angsur berubah. Beliau juga mengatakan sebelum kedatangan Pastor Elpidius van Duijhoven ke Saribudolok masyarakat sekitar masih banyak yang belum beragama tetapi setelah kedatangan Pastor Elpidius van Duijhoven banyak masyarakat Saribudolok yang memeluk Agama Katolik.

Sedangkan Bapak Simon Saragih yang penulis wawancarai pada tanggal 10 Juni 2016 masyaraka Simalungun Atas tentunya sangat bersyukur karena kedatangan Pastor Elpidius van Duijhoven. Bapak Simon Saragi mengatakan di waktu sebelum kedatangan Pastor Elpidius van Duijhoven masyarakat Simalungun atas masih penganut agama tradisional. Beliau juga mengatakan Pastor Elpidius van Duijhoven bisa dikatakan penyelamat Simalungun.

Dari hasil wawancara penulis dengan narasumber, dapat jelas kita lihat kondisi religi masyarakat Simalungun khususnya daerah Simalungun Atas berubah 
sejak kedatangan Pastor Elpidius van Duijhoven, dulu masyarakat Simalungun Atas, seperti Saribudolok, Purba Hinalang, Haranggaol masih menganut aliran kepercayaanseperti "Sinumbah" dan "Siamagod". Masyarakat sudah mulai berangsur- angsur memeluk Agama Katolik. Masyarakat sudah mulai meninggalkan hal-hal gaib dan mulai mempercayai Agama Katolik yang dibawa oleh Yesus Kristus.

Hal ini ditandai dengan banyaknya gereja yang berdiri di wilayah Saribudolok dan sekitarnya, bahkan Saribudolok sendiri menjadi gereja pusat atau paroki yang besar dan memiliki umat yang banyak. Paroki Saribudolokbahkan mempunyai stasi atau gereja sebanyak 61 gerejadanjumlahumat per Desember 2009 sekitar 30.553. Selain itu hal lain yang juga dapat kita lihat banyaknya umat dari Saribudolok yang menjadi Pastor maupun Biarawati.

Masyarakat Saribudolok tidak serta merta langsung memeluk Agama Katolik. Banyak masyarakat yang memeluk agama Katolik dikarenakan hal-hal luar biasa yang dilakukan oleh Pastor Elpidius van Duijhiven, seperti berjalan sendiri tanpa rasa takut untuk mengunjungi masyarakat Simalungun, selalu membawa obat dan makanan serta lolos dari ujian-ujian gaib dari para "datu" atau dukun.

\section{Peranan Elpidius van Duijhoven dalam Menyebarkan Agama Katolik di Simalungun}

Setelah berhasil membaptis masyarakat Simalungun atas tentunya Pastor Elpidius van Duijhoven melakukan banyak hal agar masyarakat Simalungun makin mantap untuk memeluk Agama Katolik. Dari berbagai sumber yang dikumpulkan peneliti dan wawancara yang dilakukan peneliti, maka peneliti dapat menyimpulkan apa saya wujud peran yang beliau lakukan selama lebih kurang 60 Tahun berada di Simalungun secara khusus di Saribudolok. Adapun wujud peranan Pastor Elpidius van Duijhoven adalah :

\section{Gereja}

Banyak Gereja atau Stasi yang didirikan oleh Pastor Elpidius van Duijhoven.Gereja yang awal didirikan oleh Pastor Elpidius van Duijhoven adalah di Sabah Dua kemudian Haranggaol dan Purba Hinalang di tahun 1936 lalu di 
Saribudolok tahun 1938.Berkat Pastor Elpidius jugalah saat ini Paroki Saribudolok menjadi pusat dan mempunyai banyak stasi atau Gereja Kecil. Menurut buku 75 Tahun Karya Gereja Katolik Paroki St. Fransiskus Asisi-Saribudolok (1935-2010) saat ini sudah ada sekitar 62 Gereja katolik yang tersebar di wilayah Simalungun yang terdiri dari beberapa rayon.

\section{Mengobati Masyarakat dan Penuh Perhatian Kepada Umat yang} Miskin dan Menderita.

Seperti yang dikatakan bapak Alfian Purba pada tanggal 7 juni 2016 dan Bapak J.P.S Manihuruk 8 Juni 2016 Pastor Elpidius selalau membawa obat yaitu Norit, vitamin dan susu untuk diberikan kepada masyarakat. Dalam setiap perjalanan Pastor Elpidius van Duijhoven tidak hanya membawa bekal untuk dirinya, tetapi juga bekal untuk umat atau masyarakat. Dia memberi dan melayani umat tanpa mengharapkan imbalan Bapak Alfian dan Bapak Manihuruk juga mengatakan saat membagikan obat dan vitamin tersebut Pastor Elpidius van Duijhoven tidak membedakan agama apa yang dianut masyarakat tersebut. Pastor Elpidius selalu memberikan kepada siapa yang membutuhkan.

\section{Mendirikan Sekolah}

Sekolah yang didirikan oleh Pastor Elpidius van Duijhoven adalah sekolah Sekolah Dasar Don Bosco. Sekolah Dasar Don Bosco Saribudolok didirikan pada tahun 1967 oleh Pastor Elpidius van Duijnhoven bersama para suster dan beberapa tokoh umat. Gedung Sekolah dasar Don Bosco waktu itu sangat sederhana terdiri dari lantai papan, tiang panggung dan dibangun dengan memakai papan bekas Asrama Putri. Sekolah ini didirikan dikarenakan keyakinan dan kebutuhan akan pentingnya pengetahuan dan pendidikan bagi masyarakat saat itu. Awalnya Sekolah Dasar Don Bosco diperuntukkan untuk pemberantasan buta huruf bagi masyarakat dan kegiatan belajar mengajar hanya terjadi pada hari Minggu. Namun jumlah murid cukup banyak mencapai 70 orang. Pada waktu itu ruangan sekolah tidak cukup untuk menampung banyaknya siswa, maka mereka dibagi dua kelompok, A dan B. Secara bergantian para siswa mempergunakan ruangan yang kecil dan serba darurat itu. Kelompok A bersekolah pada pagi hari sedangankan kelompok B 
bersekolah pada siang hari. Melihat antusiasme masyarakat menyekolahkan anaknya,tidak lama kemudian tepatnya pada tanggal 1 Juli 1968 dibangunlah gedung semi permanen.

Selain SD Don Bosco ada satu sekolah lagi yang di usulkan oleh Pastor Elpidius van Duijhoven. SMA Cinta Rakyat Duijnhoven yang berdiri tahun 1986, diprakarsai oleh Pastor Raymond Simanjorang, OFM Cap bersama dengan Dewan Pastoral Paroki Saribudolok. Latar belakang didirikan sekolah ini adalah saat Pastor Elpidius melaksakan pesta emas Imamat. Dalam diskusi dan pembahasan, panitia memutuskan untuk membangun monumen/ patung Pastor Elpidus van Duijhoven di depan gereja Paroki Saribudolok. Akan tetapi ide tersebut kurang berkenan di hati Pastor Elpidius van Duijhoven, Pastor Elpidius mengatakan, saya tidak mau tugu yang mati, saya jauh lebih bahagia jika anak-anak paroki ini bisa bersekolah. Dengan ungkapan itu munculah ide untuk mendirikan sekolah sebagai hadiah pengabdian dan karya Pastor Elpidius van Duijnhoven selama di Paroki Saribudolok. Akhirnya panitia menyepakati pendirikan SMA yang akan diberi nama SMA Van Duijnhoven.

\section{PENUTUP}

Berdasarkan hasil penelitian dan pembahasan yang telah dilakukan maka diperoleh kesimpulan bahwa Masyarakat yang ada di Simalungun, khususnya Saribudolok sebelum tahun 1935 atau sebelum kedatangan Pastor Elpidius van Duijhoven tersebut sudah memiliki kepercaayan. Kepercayaan yang dianut oleh masyarakat adalah terhadap roh nenek moyang dan agama Kristen yang dibawa oleh HKBPS yang kemudian menjadi GKPS.Pastor Elpidius van Duijhoven merupakan missionaris pertama yang datang ke daerah Simalungun Atas di tahun 1935.

Penyebaran Agama Katolik di Simalungun dimulai di Sabah Dua sekitar 7 Km dari Pematang Siantar. Di Sabah Dua Elpidius mendirikan stasi dan terus berjalan hingga ke Sirpang Sigodang kemudian ke Pematang Raya. Setelah mengalami banyak rintangan di Pematang Raya, Elpidius menyebarkan Agama Katolik ke Pematang Purba kemudian ke Haranggaol dan terus ke Saribudolok 
hingga ke Karo dan Lau Deski Aceh Tenggara.Setelah mampu menyebarkan Agama Katolik di Simalungun, Pastor Elpidius menjadikan Saribudolok menjadi pusat persebaran dikarenakan Saribudolok sengaja dipilih karena desa itu merupakan pusat perdagangan dan letaknya sentral antara Pematang siantar dan Aceh Tenggara, kebetulan juga di Saribudolok sudah ada stasi kecil. Stasi inilah yang menjadi pusat kegiatan gerejani bagi Elpidius pada awalnya.

Dalam menjalankan peranannya untuk menyebarkan Agama Katolik Pastor Elpidius tidak sendiri, Pastor Elpidius dibantu dengan beberapa Katekis.Katekis tersebut adalah Kenan Mase Hutabarat, kemudian Laur Viator Hutabarat yang menemani di Sabah Dua. Kemudian ada Petrus Datubara dari Purba Hinalang. Selain itu juga dibantu oleh Pastor Nepomucenus Hamers seorang Pastor yang bertugas di Sidikalang. Sementara di Saribudolok sendiri Pastor Elpidius di temani oleh Katekis Bonaventura Yaep Lin Hin Purba.Peranan yang dilakukan oleh Pastor Elpidius van Duijhoven dalam menyebarkan Agama Katolik adalah dengan cara mendirikan gereja yang saat ini mencapai 62 gereja, membantu masyarakat tanpa pandang bulu, serta mendirikan sekolah.

\section{DAFTAR REFERENSI}

Agustono, Budi Dkk.(2012). Sejarah Etnis Simalungun. Medan:USU Aster, Gentilis.(2008). Kepentingan Kita Berbeda Lima Puluh Tahun Misi Kapusin Di Sumatera (1911-1961).Medan

Badan Pusat Statistik. (2014). Silimakuta Dalam Angka 2014. Badan Pusat Statistik Kabupaten Simalungun.

Daliman, A.(2012).Metode Penelitian Sejarah.Yogyakarta:Ombak. Gottschalk, Louis. (1997). Mengerti Sejarah. Jakarta : UI Press. Jansen, Arlin D.(2003).Gonrang Simalungun.Medan:Bina Media Perintis Joosten, Leo.(2005). Tali Pengukur Jatuh Ke Tanah Permai.Medan:Bina Media Perintis

Koentjaraningrat.(2009). Pengantar Ilmu Antropologi. Jakarta : Rineka Cipta. Ningsih, Trivai.(2012).Peranan Misionaris Dalam Menyebarkan Agama Katolik di Sidikalang Kabupaten Dairi (1938-1944).Medan:Unimed

Saragih, Simon.(2014).Elpidius Van Duijhoven Oppung Dolok Rasul dari Simalungun Atas Sungguh Mati dia Mencintai Umatnya.Medan.Bina Media Perintis

Scharf. Bety R.(2004).Sosiologi Agama.Jakarta:Kencana

Soekanto, Soejono. (2012). Sosiologi Suatu Pengantar. Jakarta : Rajawali Pers 